Paedagogia Christiana

2/30 (2012) - ISSN 1505-6872

Matgorzata Stowik*

Słupsk

\title{
O potrzebie rozwoju poradnictwa rodzinnego opartego na wartościach chrześcijańskich \\ - na przykładzie dzialalności Kościoła katolickiego w Polsce
}

\section{Wprowadzenie}

Rodzina jest przedmiotem badań w wielu środowiskach. Wiedza o niej jest obszerna, podobnie jak praktyka pracy z nią, stąd nowy autonomiczny kierunek: nauki o rodzinie, łączący różne sposoby jej pojmowania i badania. Chcąc zaprezentować kondycję rodziny współczesnej, należy sięgnąć do aktualnych opracowań, które wskażą główne kierunki jej przemian. Duży niepokój wśród badaczy rodziny - familiologów - wzbudzają takie zjawiska, jak: wzrost liczby rozwodów, wzrost liczby związków pozamałżeńskich i związany z tym wzrost liczby urodzeń pozamałżeńskich (tabela 1 , tabela 2). Uzasadnienie tych zjawisk znajdziemy w analizie współczesnej rzeczywistości społeczno-kulturowej, w intensywności zagrożeń (narastających problemach społecznych, takich jak: bezrobocie, uzależnienia, prze-

* Dr Małgorzata Słowik jest adiunktem w Instytucie Pedagogiki w Akademii Pomorskiej w Słupsku.

Por. T. Sakowicz, „Bitwa o rodzinę czy walka z rodzinq” - dylematy wspótczesnej rzeczywistości społecznej Polski, w: H. Marzec, M. Pindera (red.), Problemy rodziny na poczqtku trzeciego tysiaclecia, t. I, Piotrków Trybunalski 2007, s. 31-49; F. Adamski, Czy rodzina ma przyszłość? Między utopijnymi wizjami a naturalnq komórkq spoteczeństwa, w: J. Jęczeń, M. Z. Stępulak (red.), Wartość i dobro rodziny, Lublin 2011. 
moc), czy też w życiu w tak zwanym chaosie aksjologicznym. To właśnie chaos aksjologiczny, czyli brak jasno określonych norm moralnych, relatywizm wartości, powoduje, że współczesna rzeczywistość w wielu dziedzinach życia okazuje się bardzo schizofreniczna: z jednej strony deklaruje się wartość rodziny, z drugiej strony nie promuje się jej w realnym działaniu, a nawet szerzy się ideologie wypaczające jej wartość. Trwają więc dyskusje nad miejscem i znaczeniem rodziny w przyszłości.

Tab. 1. Małżeństwa zawarte i rozwiazane

\begin{tabular}{|l|r|r|r|r|r|}
\hline & $\mathbf{1 9 9 5}$ & $\mathbf{2 0 0 0}$ & $\mathbf{2 0 0 5}$ & $\mathbf{2 0 0 9}$ & $\mathbf{2 0 1 0}$ \\
\hline $\begin{array}{l}\text { Małżeństwa } \\
\text { zawarte }\end{array}$ & 207,1 tys. & 211,2 tys. & 206,9 tys. & 250,8 tys. & 228,3 tys. \\
\hline $\begin{array}{l}\text { Małżeństwa } \\
\text { rozwiązane }\end{array}$ & 214,5 tys. & 209,8 tys. & 228,9 tys. & 229,0 tys. & 220,7 tys. \\
\hline przez śmierć & 176,4 tys. & 167,0 tys. & 161,3 tys. & 163,6 tys. & 159,4 tys. \\
\hline przez rozwód & 38,1 tys. & 42,8 tys. & 67,6 tys. & 65,3 tys. & 61,3 tys. \\
\hline $\begin{array}{l}\text { Małżeństwa } \\
\text { istniejące } \\
\text { (w dniu } \\
\text { 31.12.2010) }\end{array}$ & 9222,1 tys. & 9186,1 tys. & 8927,6 tys. & 8978,6 & 8984,9 tys. \\
\hline
\end{tabular}

Źródło: Mały rocznik statystyczny Polski GUS 2011.

Tab. 2. Urodzenia (żywe)

\begin{tabular}{|l|r|r|r|r|r|}
\hline & $\mathbf{1 9 9 5}$ & $\mathbf{2 0 0 0}$ & $\mathbf{2 0 0 5}$ & $\mathbf{2 0 0 9}$ & $\mathbf{2 0 1 0}$ \\
\hline $\begin{array}{l}\text { Urodzenia } \\
\text { małżeńskie }\end{array}$ & $\begin{array}{r}\text { brak } \\
\text { danych }\end{array}$ & 332,4 tys. & 297,1 tys. & 333,0 tys. & 328,2 tys. \\
\hline $\begin{array}{l}\text { Urodzenia } \\
\text { pozamałżeńskie }\end{array}$ & brak & 45,9 tys. & 67,2 tys. & 84,5 tys. & 85,0 tys. \\
\hline Razem & 433,1 tys. & 378,3 tys. & 364,3 tys. & 417,5 tys. & 413,0 tys. \\
\hline
\end{tabular}

Źródło: Rocznik Demograficzny GUS 2011.

Pojawia się potrzeba wsparcia rodziny, przez długi czas zaspokajana w naturalny sposób przez osoby najbliżej spokrewnione, a także w obrębie rodziny dalszej (w formie wsparcia krewnych, przyjaciół), czy w otoczeniu 
sąsiedzkim oraz przez wpływ takich autorytetów, jak: szkoła, Kościół, które w kulturze europejskiej długo działały w zgodzie z wyznawanymi wartościami chrześcijańskimi.

Jedną z form pomocy, oferowanych współcześnie rodzinom, jest poradnictwo rodzinne. W Polsce funkcjonuje ono zarówno w instytucjach publicznych - świeckich, jak i w ramach działania różnych Kościołów. Świeckie podstawy poradnictwa rodzinnego wydają się jednak coraz bardziej oddalać od chrześcijańskich. Prawo świeckie normalizuje sytuacje, które w rzeczywistości osłabiają wartość małżeństwa i rodziny, czyli współtworzy politykę, która wbrew wzniosłym założeniom w praktyce nie okazuje się prorodzinna, ale raczej antyrodzinna ${ }^{2}$.

W tej pracy przyjrzymy się wyzwaniom, jakie stają przed katolickim poradnictwem rodzinnym. Interesuje nas głównie odkrycie specyfiki $i$ wyjatkowego charakteru katolickiego poradnictwa rodzinnego oraz określenie możliwości i niedomogów w świadczeniu tej formy pomocy w Polsce.

\section{Poradnictwo rodzinne laickie w Polsce - rozwój, istota}

Sam termin ,poradnictwo” bywa rozmaicie definiowany. A. Kargulowa wskazuje kilka sposobów rozumienia poradnictwa: poradnictwo jako działanie społeczne, jako interakcja osobowa, jako działalność zorganizowana, jako forma pomocy społecznej ${ }^{3}$. S. Murgatroyd przywołuje definicję Amerykańskiego Towarzystwa Psychologicznego, zgodnie z którą poradnictwo jest ,pomaganiem poszczególnym jednostkom w pokonywaniu przeszkód znajdujących się na drodze do osobistego rozwoju, gdziekolwiek je napotykają, oraz w optymalnym pobudzaniu indywidualnych źródeł tego rozwoju”4. W. Szewczyk przyjmuje, że ,poradnictwo jest osobowym kontaktem pomocnym” i tłumaczy znaczenie użytych terminów: „kontaktem” określa wzajemne odniesienie, spotkanie, którego narzędziem jest słowo, rozmowa, wymiana słów, dialog; kontakt „osobowy” w przeciwieństwie do rzeczowego oznacza kontakt osoby z osobą, z całym jej osobowym wyposażeniem (światem myśli, wyobrażeń i postaw); ,pomocny” wskazuje na cel osobowego kontaktu: na szeroko lub bardzo konkretnie rozumianą pomoc (od emo-

2 Por. J. M. Jackowski, Czas rodzin, Szczecinek 2007.

${ }^{3}$ A. Kargulowa, O teorii i praktyce poradnictwa. Podręcznik akademicki, Warszawa 2004, s. 37-55.

${ }^{4}$ S. Murgatroyd, Poradnictwo i pomoc, Poznań 2000, s. 16. 
cjonalnego wsparcia $\mathrm{w}$ trudnej sytuacji do realnej pomocy w rozwiązaniu problemu $)^{5}$.

Spośród wielu dziedzin szeroko rozumianego poradnictwa wyodrębniono poradnictwo rodzinne, które skierowane jest na relacje osób w ich najważniejszym środowisku życia, jakim jest środowisko rodzinne. W literaturze przedmiotu określa się różny zakres tego poradnictwa: dotyczyć może ono albo całości zagadnień związanych z funkcjonowaniem rodziny w różnych fazach życia, albo też poszczególnych jego działów (wówczas poza poradnictwem rodzinnym wymienia się: poradnictwo przedmałżeńskie, małżeńskie, wychowawcze, seksualne) ${ }^{6}$. Komisja Dialogu Społecznego ds. Poradnictwa Specjalistycznego, przygotowując Standardy udzielania poradnictwa specjalistycznego, w tym rodzinnego, przyjęła następującą definicję poradnictwa rodzinnego/małżeńskiego:

[poradnictwo rodzinne/małżeńskie - przyp. autora] ma na celu poprawę jakości życia w małżeństwie i rodzinie przez udzielanie fachowej konsultacji oraz dzielenie się własnym doświadczeniem w tym zakresie. Obejmuje zespół działań wspomagających budowanie relacji międzyosobowych. Dotyczy takich sfer życia jak przygotowanie do małżeństwa, problemy w małżeństwie, dzieci i ich wychowanie, więź międzypokoleniowa, kultura życia rodzinnego, itp. Poradnictwo rodzinne może być prowadzone przez psychologów, pedagogów, mediatorów oraz przez osoby, które przeszły przygotowanie właściwe organizacji pozarządowej, zajmującej się tą tematyką. Działania podejmowane przez te osoby mogą być dodatkowo wspierane przez specjalistów różnych dziedzin. Efektem poradnictwa rodzinnego powinna być zdolność klienta do samodzielnego rozwiązywania problemów małżeńskich i rodzinnych oraz podnoszenie kultury życia rodzinnego?

5 W. Szewczyk, Poradnictwo rodzinne - osobowy kontakt pomocny, „Homo Dei” 1 (1999), s. 52-61; tenże, Poradnictwo rodzinne. Program szkoleniowy dla Ośrodków Polonijnych, Hanover-Tarnów 2011, s. 40.

${ }^{6}$ A. Kargulowa, O teorii, s. 43; D. Kowalczyk, Poradnie rodzinne, w: J. Bragiel, S. Badora (red.), Formy opieki, wychowania $i$ wsparcia $w$ zreformowanym systemie pomocy spotecznej, Opole 2005, s. 153.

${ }^{7}$ Komisje dialogu społecznego są gremiami inicjatywno-doradczymi, tworzonymi przez zainteresowane organizacje pozarządowe oraz miasto stołeczne Warszawę. Ich charakter, polegający na współdziałaniu środowiska pozarządowego i urzędniczego, powoduje, że są one podstawowym partnerem w wypracowywaniu rozwiązań w poszczególnych dziedzinach zadań publicznych należących do miasta stołecznego Warszawy.

http://archiwumngo.um.warszawa.pl/files/File/kds_poradnicza_03_02_09.pdf (03.11.2011) 
Poradnictwo rodzinne w Polsce rozwija się od lat 50. ubiegłego wieku. Wówczas udzielaniem porad rodzinnych zajmowały się w wybiórczy sposób nieliczne poradnie. Należały do nich placówki Towarzystwa Planowania Rodziny, które koncentrowało się głównie na problematyce dostosowania seksualnego w związku partnerskim i problematyce świadomego macierzyństwa (przy uwzględnieniu psychologicznego i socjologicznego kontekstu porad). Liga Kobiet organizowała w tym czasie poradnictwo prawne i psychologiczno-pedagogiczne w ramach działalności poradni prawno-społecznych. W sytuacji doświadczania problemów wychowawczych rodzice mogli korzystać $z$ usług poradni zdrowia psychicznego dla dzieci i młodzieży (resort zdrowia i opieki społecznej) i były one wówczas jedynymi placówkami udzielającymi porad w sprawach małych dzieci. Poradnictwo wychowawcze dla dzieci i młodzieży realizowane było zaś przez poradnie wychowawczo-zawodowe (resort oświaty i wychowania) ${ }^{8}$.

Pierwszą placówką ujmującą poradnictwo rodzinne w sposób kompleksowy była Poradnia dla Rodziców i Dzieci, działająca w latach 1962-1968 przy Zakładzie Pediatrii Społecznej Akademii Medycznej w Warszawie9. Rodzice mogli w niej uzyskać poradę psychologiczną, wychowawczą i lekarską w sprawach dzieci, a także we własnych małżeńskich sprawach i w kwestiach relacji z innymi członkami rodziny.

Zdaniem A. Kargulowej, wraz ze zmianami społeczno-ustrojowymi zapoczątkowanymi w 1989 roku nastąpiła wręcz ,eksplozja” poradnictwa, szczególnie prywatnego-komercyjnego ${ }^{10}$. Zmieniająca się rzeczywistość społeczna, nowe problemy społeczne, a także komercjalizacja i konkurencyjność usług poradnianych, inspirują do wprowadzania innowacyjnych działań w poradnictwie. Mimo to, dostępność do nieodpłatnych porad z zakresu poradnictwa rodzinnego wciąż pozostaje niewystarczająca. Jest to szczególnie istotny problem w odniesieniu do rodzin korzystających z pomocy społecznej. Należy więc podkreślać znaczenie i potrzebę rozwoju poradnictwa rodzinnego w systemie pomocy społecznej, zarówno w formie zintegrowanych instytucjonalnych działań (publicznych poradni rodzinnych lub działalności wyspecjalizowanych komórek usytuowanych przy ośrodkach pomocy społecznej), jak i w formie działań podejmowanych przez pracowników socjalnych $w$ ich indywidualnych kontaktach $\mathrm{z}$ rodzinami ${ }^{11}$.

${ }^{8}$ M. Ziemska, Rodzina a osobowość, Warszawa 1975, s. 172.

9 Tamże.

${ }^{10}$ A. Kargulowa, Przeciw bezradności. Nurty - opcje - kontrowersje w poradnictwie i poradoznawstwie, Wrocław 1996, s. 102.

${ }^{11}$ M. Słowik, Przygotowanie studentów pracy socjalnej do świadczenia poradnictwa rodzinnego, wykład wygłoszony na V Międzynarodowej Konferencji Ocalić rodzinę-ocalić 


\section{Rozwój poradnictwa rodzinnego opartego na wartościach chrześcijańskich}

\subsection{Doświadczenia polskie}

Odmiennie kształtowało się parafialne poradnictwo rodzinne, którego początki związane są z wprowadzeniem w roku 1956 ustawy o dopuszczalności przerywania ciąży ${ }^{12}$. Powołano wówczas krajowe i diecezjalne Duszpasterstwo Pracowników Lecznictwa, które miało upowszechniać wiedzę o możliwościach regulacji poczęć zgodnych z etyką chrześcijańską (początkowo w środowisku lekarskim, a potem także wśród rodzin). W 1960 roku powstało Krajowe Duszpasterstwo Rodzin, a w 1965 roku Komisja Episkopatu do Spraw Duszpasterstwa Rodzin. Wtedy też powołano instruktorki diecezjalne, które zajęły się przygotowaniem świeckich kadr dla potrzeb poradnictwa rodzinnego. Jednocześnie przy większych parafiach tworzono punkty poradnictwa rodzinnego.

Uczenie planowania rodziny przez stosowanie metod naturalnych początkowo miało miejsce w zasadzie tylko w Kościele i przez nielicznych lekarzy. Zajmowali się nim: dr T. Kramarek, dr J. Massalska, dr W. Półtawska, dr W. Fijałkowski. W miarę rozwoju wiedzy medycznej i większego zaangażowania lekarzy praktyków (na przykład dr Rötzera) i naukowców (na przykład dr Billingsa, prof. Odeblatt) powstały warunki, w których mogła zostać utworzona Papieska Akademia Życia i różne szkoły metod naturalnych.

Parafialne poradnictwo rodzinne posiadało zawsze wyraźne podstawy teoretyczne, oparte na chrześcijańskiej koncepcji filozoficzno-teologicznej. Wraz z upływem czasu rozrastała się jego sieć. W ramach duszpasterstwa rodzin utworzono wiele poradni skupiających specjalistów wielu dziedzin. Działalność poradniczą, początkowo skupioną na upowszechnianiu naturalnych metod planowania rodziny, poszerzono o poradnictwo dla narzeczonych $\mathrm{w}$ formie wykładów, indywidualnych porad ${ }^{13}$. Wciąż jednak odczuwa się niedosyt $\mathrm{w}$ zakresie rozwoju poradnictwa dla małżeństw i rodzin,

przyszłość 24-25 marca 2011 roku na Uniwersytecie w Rzeszowie (w oczekiwaniu na publikację).

12 Ustawa o warunkach dopuszczalności przerywania ciąży z 27 kwietnia 1956 roku - zezwalająca na przerywanie ciąży ze wskazań społecznych, lekarskich oraz prawnych; Rozporządzenie Ministra Zdrowia z 19 grudnia 1959 roku w sprawie przerywania ciąży - umożliwiające w praktyce przerywanie ciąży na żądanie.

${ }^{13}$ T. Kukołowicz, Rodzinne poradnictwo parafialne, „Zeszyty Naukowe Instytutu Badania Prawa Sądowego" 31 (1991), s. 295; A. Kargulowa, Przeciw bezradności, s. 72. 
czego dowodem może być zgłaszane przez doradców rodzinnych zjawisko: spośród rzeszy par narzeczonych, które obligatoryjnie korzystają z poradnictwa w zakresie przygotowania do sakramentu małżeństwa, niewielki procent kontaktuje się z nimi ponownie, będąc już małżonkami czy rodzicami ${ }^{14}$.

\subsection{Dokumenty Kościoła źródłem powstania poradnictwa rodzinnego}

Podstawą rozwoju duszpasterstwa rodzin i poradnictwa rodzinnego w Kościele była encyklika Pawła VI Humanae vitae z 1968 roku i adhortacja apostolska Jana Pawła II Familiaris consortio z 1981 roku oraz dokumenty wydane przez Episkopat Polski:

- Pierwsza Instrukcja Episkopatu Polski dla duchowieństwa o przygotowaniu wiernych do sakramentu matżeństwa i o duszpasterstwie rodzin (12.02.1969),

- Druga Instrukcja Episkopatu Polski dotyczqca przygotowania do matżeństwa i życia rodzinnego oraz wprowadzenia nowego obrzędu sakramentu malżeństwa (11.03.1975),

- Instrukcja Episkopatu Polski o przygotowaniu do zawarcia małzeństwa w Kościele katolickim (13.12.1989),

- Dyrektorium Duszpasterstwa Rodzin (01.05.2003).

Dokumenty te zostaną poddane analizie z zamiarem odkrycia i opisania ważnych cech poradnictwa rodzinnego, jakie powinno funkcjonować w Kościele katolickim. Zwróci się przy tym uwagę na powodzenia, przeszkody lub zaniedbania w realizowaniu określonych wytycznych.

Wydanie encykliki Humanae vitae przez Pawła VI w 1968 roku wzbudziło wiele kontrowersji, najwięcej w społeczeństwach, których kultura opiera się na ideologii konsumpcji i hedonizmu, czyli w krajach Europy Zachodniej i w Ameryce Północnej ${ }^{15}$. Papież poruszył bardzo istotny, ale i drażliwy w ówczesnych czasach temat: powołania małżeństwa do przekazywania życia. W kontekście tego powołania Papież wyjaśnia w encyklice normy życia małżeńskiego i odpowiedzialnego rodzicielstwa. Zdając sobie

${ }^{14}$ A. Mrozowicz, Raport o sytuacji Poradnictwa Rodzinnego w Archidiecezji Gdańskiej na podstawie badań socjologicznych przeprowadzonych wśród Doradców Życia Rodzinnego, Gdańsk 2008, s. 22. Raport ten opracowany został w oparciu o badania sondażowe przy użyciu ankiety, przeprowadzone na przełomie lat 2007-2008 wśród doradców życia rodzinnego pracujących w środowisku Poradnictwa Rodzinnego Archidiecezji Gdańskiej. Średni odsetek par nawiązujących ponowny kontakt z poradnią wyniósł $0,3 \%$ na jednego doradcę.

15 Por. Paweł VI, Encyklika Humanae Vitae oraz komentarz teologów moralistów środowiska krakowskiego pod kierunkiem Karola kardynała Wojtyly (przedruk z: „Notificationes e curia Metropolitana Cracoviensi” 1-4 [1969], s. 71-105) - w tekście HV z odnośnym numerem. 
sprawę z trudności w praktykowaniu tych norm we współczesnym świecie, w trzeciej części omawianego dokumentu proponuje ,apostolat rodzin wśród rodzin":

Wśród owoców, które dojrzewaja, gdy prawo Boże jest gorliwie przestrzegane, niezwykle cenny jest ten, że sami małżonkowie często pragną podzielić się z innymi wynikami swoich doświadczeń. Dzięki temu w szerokich ramach powołania świeckich znajdzie się nowa i niezwykle doniosła forma apostolatu, w której równi usługują równym. Wtedy bowiem sami małżonkowie podejmują zadanie apostolskie względem innych małżonków, pełniąc rolę ich przewodników. Wśród tylu form chrześcijańskiego apostolatu ta wydaje się obecnie najpotrzebniejsza (HV 26).

Chcąc promować chrześcijański styl życia, warto odwołać się do pomocy ludzi, którym się to udaje, nawet w tak zsekularyzowanym świecie. Dlatego słusznie podpowiada Papież: małżeństwom borykającym sie z trudnościami łatwiej pomogą te małżeństwa, które stawały już w obliczu podobnych problemów i potrafily je rozwiązać w sposób chrześcijański.

To wskazanie można uznać za podstawy formowania się poradnictwa rodzinnego w Kościele katolickim. Zaproszenie świeckich do pomocy innym świeckim w celu umacniania lub ratowania życia rodzinnego, zgodnie z nauką Kościoła, zapoczątkowało działania na rzecz rozwoju poradnictwa rodzinnego.

W adhortacji apostolskiej Jana Pawła II Familiaris consortio z 1981 roku, po omówieniu sytuacji rodzin współczesnych, ukazaniu zamysłu Bożego względem nich oraz wyjaśnieniu zadań rodziny chrześcijańskiej, podjęto temat pilnej potrzeby rozwoju duszpasterstwa rodzin. Cała część czwarta adhortacji, zatytułowana: Duszpasterstwo rodzin: etapy, organizacja, pracownicy i okoliczności, pokazuje, jak wielką rolę, konkretne zadania, a także propozycje pomocy przewidywał Papież dla rodziny chrześcijańskiej we współczesnym świecie. Papież założył, że: „Trzeba podjąć każdy wysiłek, ażeby zorganizować i rozwinąć duszpasterstwo rodzin, troszcząc się o tę pierwszoplanową dziedzinę w przekonaniu, że przyszłość ewangelizacji zależy w wielkiej mierze od «Kościoła domowego»" (FC 65) ${ }^{16}$.

Choć w adhortacji jest mowa o duszpasterstwie rodzin, a nie poradnictwie rodzinnym, można przyjąć, że poradnictwo rodzinne, działające w obrębie Kościoła katolickiego, wyłoniło się właśnie z duszpasterstwa rodzin

16 Jan Paweł II, Adhortacja apostolska Familiaris consortio o zadaniach rodziny chrześcijańskiej w świecie współczesnym, w: Adhortacje apostolskie Ojca Świętego Jana Pawła II Kraków 1997 - w tekście FC z odnośnym numerem. 
i uzupełnia je o bardziej specjalistyczną pomoc, na przykład pomoc psychologiczna, prawna, medyczną ${ }^{17}$.

W Familiaris consortio znajdziemy wytyczne na temat organizowania przygotowania do małżeństwa, które powinno być procesem długotrwałym, ciagłym i stopniowym. Ma obejmować trzy podstawowe etapy: przygotowanie dalsze, bliższe i bezpośrednie. Za przygotowanie do małżeństwa mają odpowiadać zarówno same rodziny, jak i Kościół:

Rodzina i cała wspólnota kościelna powinny poczuwać się do współdziałania w poszczególnych etapach przygotowania do małżeństwa [...]. Byłoby pożądane, ażeby Konferencje Episkopatów [...] postarały się o wydanie Dyrektorium duszpasterstwa rodzin. To Dyrektorium powinno przede wszystkim ustalić zakres tematów, czas trwania i metody «kursów przygotowawczych», z zachowaniem równowagi między różnymi aspektami - doktrynalnym, pedagogicznym prawnym i medycznym - dotyczącymi małżeństwa i taką nadać im strukturę, ażeby przygotowujący się do małżeństwa, obok pogłębienia intelektualnego, poczuli się zachęceni do żywego włączenia się we wspólnotę kościelną (FC 66).

W Polsce Dyrektorium Duszpasterstwa Rodzin zostało zatwierdzone w 2003 roku.

Oprócz działań adresowanych do osób przygotowujących się do sakramentu małżeństwa, Familiaris consortio określa też potrzebę wspierania samych małżeństw. Pomoc małżeństwu przekłada się na życie całej rodziny. Szczególnym, trudnym czasem dla małżeństwa Jan Paweł II określił pierwsze lata po ślubie, kiedy małżonkowie poznają się w nowych rolach, przyjmują na świat kolejne dzieci. Pojawiają się wówczas trudności związane ze znanym z psychologii małżeństwa i rodziny kryzysem pierwszego dziecka czy przeżywaniem fazy: małżeństwo $\mathrm{z}$ dziećmi w wieku przedszkolnym. W omawianej adhortacji znajduje się zachęta:

17 Duszpasterstwo to zorganizowana działalność społeczna Kościoła polegająca na głoszeniu zasad wiary, celebrowaniu liturgii w różnych grupach, nad którymi opiekę ze strony Kościoła sprawuje duszpasterz. Duszpasterstwo rodzin w Kościele katolickim jest działem duszpasterstwa, którego działanie koncentruje się wokół rodziny jako podstawowej komórki Kościoła. Por. B. Mierzwiński, Elementy teologii praktycznej matżeństwa i rodziny, w: K. Majdański (red.), Teologia małżéstwa i rodziny, t. 1, Warszawa 1980, s. 157-227; J. Kłys, Podmiotowe uwarunkowania duszpasterstwa rodzin, w: K. Majdański (red.), dz. cyt., t. 2, Warszawa 1990, s. 111-161; B. Mierzwiński, Duszpasterstwo Rodzin, w: E. Ozorowski (red.), Słownik Małżeństwa i Rodziny, Warszawa-Lomianki 1999, s. 100-101. 
Niech młodzi małżonkowie umieją serdecznie przyjąć i rozumnie ocenić dyskretną, delikatną i wielkoduszną pomoc innych małżeństw, które już od dawna przeżywają doświadczenia małżeństwa i rodziny. W ten sposób, w łonie wspólnoty kościelnej - wielkiej rodziny rodzin chrześcijańskich - będzie się dokonywała wzajemna wymiana obecności i pomocy pomiędzy wszystkimi rodzinami, w której każda ofiaruje na rzecz innych własne, ludzkie doświadczenia, a także podzieli się darami wiary i łaski (FC 69).

Zachęta do korzystania z pomocy innych małżeństw pojawiła się już w encyklice Humanae vitae ( $\mathrm{nr} 26$ ) i na pewno jest dobrym pomysłem. Tu jednak, w obu przywoływanych wyżej dokumentach (encyklice i adhortacji), nie określono, na jakich zasadach, w jaki sposób małżeństwa mogą nawzajem sobie pomagać. Chcąc świadczyć poradnictwo rodzinne, trzeba do tego odpowiednio przygotować wybrane osoby i tę konieczność uwzględniono w późniejszych dokumentach, na przykład w analizowanych poniżej instrukcjach Episkopatu Polski i Dyrektorium Duszpasterstwa Rodzin.

Wśród pracowników duszpasterstwa rodzin przewidziano tak zwanych specjalistów świeckich: „Wiele pomóc mogą rodzinom ci specjaliści świeccy (lekarze, prawnicy, psychologowie, pracownicy społeczni, doradcy, itp.), którzy czy to indywidualnie, czy w różnych stowarzyszeniach lub akcjach służą im poprzez naświetlanie spraw, radę, wskazywanie kierunku, oparcia” (FC 75). Jan Paweł II skierował do nich słowa pochodzące z jego przemówienia do Konfederacji Chrześcijańskiego Poradnictwa Rodzinnego z dnia 29 listopada 1980 roku: „...Wszystko, co zdołacie uczynić, by pomóc rodzinie, jest z natury rzeczy skierowane ku osiagnięciom, które przekraczając swój własny krag, będą miały wpływ również na inne osoby i wycisną piętno na społeczeństwie. Przyszłość świata i Kościoła idzie poprzez rodzinę" (FC 75).

W Familiaris consortio zwrócono uwagę na potrzebę niesienia pomocy rodzinom znajdującym się w szczególnie trudnych sytuacjach, wśród których wymieniono: rodziny na emigracji zarobkowej, rodziny wojskowych, marynarzy (przebywających długo poza domem), rodziny więźniów, uchodźców i rodziny żyjące na marginesie życia społecznego, rodziny bez mieszkania, rodziny niepełne, rodziny z dziećmi upośledzonymi lub dotkniętymi narkomanią, rodziny alkoholików, rodziny dyskryminowane, rodziny małżonków małoletnich, osoby starsze, nierzadko zmuszone do życia w samotności, ubóstwie (FC 77).

Tak jak w przypadku zaproszenia małżeństw do świadczenia pomocy innym małżeństwom, tak tutaj, wobec wymienionych kategorii trudnych sytuacji rodzinnych, nie znajdujemy konkretnych propozycji, kto i w jaki sposób ma pomagać. Można przypuszczać, że treść analizowanych dokumentów 
stanowi inspirację do podejmowania kolejnych działań w obrębie kościołów partykularnych, dostosowanych do lokalnych warunków. Wymienione wyżej trudne sytuacje rodzinne wymagają na pewno nie tylko duszpasterskiej, ale bardziej specjalistycznej pomocy: na przykład wsparcia i pracy psychologicznej, pracy socjalnej, pomocy prawnej, medycznej, animacji w środowisku lokalnym. Łączenia tych form podjąć się może integralne poradnictwo rodzinne, funkcjonujące już obecnie w Kościele katolickim, niestety wciąż w ograniczonym zakresie - głównie w ośrodkach diecezjalnych.

Wyzwaniem dla rozwijającego się katolickiego poradnictwa rodzinnego są na pewno wymienione $\mathrm{w}$ analizowanej adhortacji niektóre sytuacje „nieregularne”, rozpowszechniające się także wśród katolików i osłabiające wartość rodziny, czyli: małżeństwa na próbę, tak zwane wolne związki, związki katolików złączonych jedynie ślubem cywilnym, sytuacje osób żyjących w separacji i rozwiedzionych niezawierających nowego związku, sytuacje rozwiedzionych, którzy zawarli nowy związek i sytuacje osób pozbawionych rodziny (FC 80-85). Nie można zamykać się przed niesieniem pomocy także im.

Do tych wszystkich osób, które cierpią z powodu trudnych sytuacji rodzinnych czy też z powodu życia w samotności, Jan Paweł II skierował słowa: „Nikt nie jest pozbawiony rodziny na tym świecie: Kościół jest domem i rodziną dla wszystkich, a szczególnie dla «utrudzonych i obciążonych» (Mt 11, 28)" (FC 85). Jest to ważne wskazanie dla pracowników poradni rodzinnych, działających przy Kościele katolickim: aby ofertę pomocy kierować do wszystkich, nie tylko do katolików. Dlatego właśnie pracownik takiej poradni, oprócz wewnętrznej duchowej formacji, powinien starać się także o zdobywanie dodatkowych kwalifikacji (w zakresie świadczenia poradnictwa dla par, dla rodziców, dla osób przeżywających kryzysy życiowe, w zakresie pracy z grupa itp.) - aby poradnictwo rodzinne nie było utożsamiane z duszpasterstwem, ale rzeczywiście uzupełniało je o specjalistyczną pomoc.

Poza dokumentami papieskimi, które stały się źródłem rozwoju poradnictwa rodzinnego w Kościele katolickim, w poszczególnych krajach ukazują się kolejne istotne dokumenty przygotowywane przez episkopaty.

Pierwsza Instrukcja Episkopatu Polski dla duchowieństwa o przygotowaniu wiernych do sakramentu matżeństwa i o duszpasterstwie rodzin z 1969 roku mówi o potrzebie rozwoju duszpasterstwa rodzin, wyodrębniając z niego poradnictwo rodzinne. Zachęca się tu duszpasterzy do skorzystania z pomocy świeckich w celu zaprowadzenia łatwo dostępnego dla potrzeb każdej parafii katolickiego poradnictwa rodzinnego: 
Laikat też powinien stanowić główną obsadę osobową przyparafialnego poradnictwa rodzinnego, pracującego w ścisłej zależności od diecezjalnego referatu duszpasterstwa rodzin [...]. Do sprawowania tych zadań, podobnie jak i do wygłaszania katechez o rodzinie i małżeństwie, dobierać należy tylko tych świeckich, którzy posiadają ku temu należyte przygotowanie i aprobatę lub misję kanoniczną biskupa ordynariusza (cz. IV, nr 3).

Osoby świeckie mogą nauczać wiernych danej parafii odpowiedzialnej regulacji poczęć, przy jednoczesnym objaśnianiu etycznych aspektów odpowiedzialnego rodzicielstwa (cz. III, nr 2). Choć omawiana instrukcja została wydana w 1969 roku, to niestety w praktyce poradnictwa rodzinnego przy parafiach wciąż zauważa się dominację nauczania metody regulacji poczęć nad objaśnianiem zasad etycznych, leżących u jej podstaw ${ }^{18}$.

W dalszej części instrukcja wskazuje, że sam proboszcz parafii powinien ułatwić rozpowszechnianie informacji o czasie i miejscu świadczenia poradnictwa rodzinnego w swojej parafii. Należy też zabiegać, aby świadczenie poradnictwa rodzinnego w parafii było stopniowo poszerzane o porady z zakresu psychologii, wychowania dzieci czy prawa (cz. III, nr 2).

Istotne jest przywołanie w instrukcji słów z encykliki Humanae vitae: „... sami małżonkowie często pragną podzielić się z innymi wynikami swoich doświadczeń. Dzięki temu w szerokich ramach powołania świeckich znajduje się nowa i niezwykle doniosła forma apostolatu, w której równi usługują równym. Wtedy bowiem sami małżonkowie podejmują zadania apostolskie względem innych małżonków, pełniąc rolę ich przewodników (HV 26)" (cz. IV, nr 2). Wartość posługi małżeństw na rzecz wspierania i pomocy innym małżeństwom jest nieoceniona, nikt nie zrozumie rzeczywistości życia w małżeństwie tak, jak sami małżonkowie. Pomoc jednych małżeństw na rzecz drugich jest realizowana w Kościele katolickim głównie w ramach działalności wybranych ruchów i wspólnot religijnych (na przykład: w Odnowie w Duchu Świętym, na Drodze Neokatechumenalnej, w Ruchu Światło-Życie, w Ruchu Rodzin Nazaretańskich, w Przymierzu Rodzin, w Ruchu Apostolskim Rodzina Rodzin itd.). Warto zapraszać małżeństwa z tych wspólnot do współpracy z poradniami rodzinnymi, po uprzednim ich przygotowaniu do prowadzenia grup wsparcia czy grup psychoedukacyjnych.

Druga Instrukcja Episkopatu Polski dotyczaca przygotowania do matżeństwa i życia rodzinnego oraz wprowadzenia nowego obrzędu sakramentu małżeństwa ogłoszona została w 1975 roku. Ze względu na wprowadzenie nowych uregulowań omówiona zostanie aktualnie obowiązująca Instrukcja Episkopatu Polski o przygotowaniu do zawarcia małżeństwa w Kościele ka-

18 A. Mrozowicz, dz. cyt., s. 24. 
tolickim ogłoszona w 1989 roku. Nawiązując do dotychczasowych postanowień i wskazań Episkopatu Polski w sprawie przygotowania wiernych do zawarcia małżeństwa, porządkuje i ujmuje w całość zawartą w nich problematykę prawną.

W Instrukcji z 1989 roku, zgodnie ze wskazaniami adhortacji apostolskiej Jana Pawła II Familiaris consortio, rozróżnia się trzy etapy przygotowania do małżeństwa: przygotowanie dalsze, obejmujące dzieci i młodzież do 17 roku życia, przygotowanie bliższe, czyli katechizację przedmałżeńską (narzeczonych), oraz przygotowanie bezpośrednie, czyli katechizację przedślubną. Każdy etap został w instrukcji szczegółowo omówiony (cz. I, nr 7-28).

Inspiracją do tworzenia struktur poradnictwa rodzinnego przy parafiach mogą być wskazówki z Kodeksu Prawa Kanonicznego, zacytowane w omawianej instrukcji:

Duszpasterze mają obowiązek troszczyć się o to, ażeby własna wspólnota kościelna świadczyła pomoc wiernym, dzięki której stan małżeński zachowa ducha chrześcijańskiego i będzie się doskonalił. Ta pomoc winna być udzielana przede wszystkim [...] poprzez świadczenie pomocy małżonkom, ażeby wiernie zachowując i chroniąc przymierze małżeńskie, osiągali w rodzinie życie coraz bardziej święte i doskonałe (KPK 1063) (cz. I, nr 5).

Skoro mowa o pomocy małżonkom, to wiadomo, że nie wystarczą już elementy przygotowania do małżeństwa - omawiane w wyżej wymienionych dokumentach, ale powstaje potrzeba tworzenia poradnictwa dla małżeństw już zawartych, dla rodzin na terenie parafii, prowadzonego nie tylko przez duszpasterzy, ale także przez osoby świeckie, specjalistów w dziedzinie świadczenia pomocy psychologicznej, pedagogicznej, prawnej, medycznej.

Myśl o potrzebie rozwoju poradnictwa rodzinnego, podejmowana w różnych dokumentach Kościoła, zyskała swoje ukoronowanie między innymi w 1975 roku w utworzeniu Instytutu, obecnie już Wydziału (od 2010 roku) Studiów nad Rodziną Uniwersytetu Kardynała Stefana Wyszyńskiego w Łomiankach, gdzie zdobywają wiedzę przyszli doradcy życia małżeńskiego i rodzinnego.

Konferencja Episkopatu Polski w 2003 roku zatwierdziła dokument $D y$ rektorium Duszpasterstwa Rodzin, opracowany przez Radę do Spraw Rodziny ${ }^{19}$. Reguluje on sprawy związane z funkcjonowaniem duszpasterstwa rodzin na

19 Obecne Dyrektorium opiera się na dotychczas wydanych dokumentach, wśród których były: Pierwsza Instrukcja Episkopatu Polski dla duchowieństwa o przygotowaniu wiernych do sakramentu matżeństwa i duszpasterstwie rodzin z 1969 roku; Druga Instrukcja Episkopatu 
terenie Kościoła w Polsce. Uwzględnia zadania osób duchownych, samych rodzin oraz laikatu zaangażowanego w tworzenie właściwych warunków dla małżeństw i rodzin. Kładzie nacisk między innymi na przygotowanie przyszłych małżonków do obowiązków rodzinnych i potrzebę tworzenia sieci placówek, które niosą pomoc rodzinie (zorganizowania domów samotnej matki, ośrodków opiekuńczo-wychowawczych, poradni, pomagających młodym małżeństwom w wychowaniu dzieci). Mają one przeciwdziałać dezintegracji rodziny i kruchości związków, pomagać rozwiązywać konflikty.

Poradnictwu i pomocy rodzinie poświęcono trzeci rozdział Dyrektorium, w którym czytamy:

Wobec narastających zagrożeń małżeństwa i rodziny z jednej strony i wobec coraz trudniejszych wyzwań, stających przed rodzinami z drugiej, należy organizować pomoc rodzinom $\mathrm{w}$ odpowiednio szerokim zakresie. Jedną $\mathrm{z}$ form pomocy narzeczonym, małżonkom i rodzicom, jest kompetentne poradnictwo rodzinne, łączące fachowość doradców z ich osobistym świadectwem życia Ewangelią [...] Wyróżnić należy: Parafialne Poradnie Rodzinne, Poradnie Specjalistyczne oraz Telefony Zaufania (nr 37).

Parafialne Poradnie Rodzinne powoływane są przez księdza proboszcza i należy dążyć, by każda parafia miała taką poradnię (nr 38). Pracować w nich mogą odpowiednio przygotowane osoby świeckie, zwane doradcami życia rodzinnego. W dyrektorium określono wymagania stawiane tym doradcom, dotyczą one: wieku, wykształcenia, predyspozycji, formacji religijnej (nr 40).

Wśród zadań Parafialnych Poradni Rodzinnych wyróżnia się:

- ukazywanie właściwego wymiaru miłości małżeńskiej i rodzinnej, w tym czystości przedmałżeńskiej i małżeńskiej;

- uwrażliwianie na godność każdego człowieka od chwili poczęcia do naturalnej śmierci;

- kształtowanie postaw prorodzinnych;

- nauczanie zasad odpowiedzialnego rodzicielstwa;

- pomoc w rozwiązywaniu konfliktów rodzinnych i problemów wychowawczych (nr 39).

Polski dotyczqca przygotowania do matżenstwa i życia rodzinnego oraz wprowadzenia nowego obrzędu sakramentu matżeństwa z 1975 roku; Instrukcja Episkopatu Polski o przygotowaniu do zawarcia matżeństwa w Kościele katolickim z 1986 roku; Instrukcja Episkopatu Polski w sprawie duszpasterstwa matżeństw o różnej przynależności kościelnej z 1987 roku; Instrukcja Papieskiej Rady ds. Rodziny: Przygotowanie do sakramentu matżeństwa z 1996 roku. 
Odnośnie do organizacji pracy w poradni przyjęto, że powinna ona dysponować własnym lokalem, estetycznie i funkcjonalnie urządzonym, zapewniającym możliwość przeprowadzania rozmów w atmosferze spokoju $\mathrm{i}$ intymności. W poradni powinny znajdować się materiały poglądowe, potrzebne do pracy doradcy, oraz odpowiednio wyposażona biblioteka. Należy też zadbać o to, by osoby korzystające z poradni miały możliwość zaopatrzenia się w odpowiednią literaturę i inne materiały. Poradnia ma być czynna w godzinach korzystnych dla danej parafii. Informacja o dniach i godzinach jej funkcjonowania ma być odpowiednio promowana $(\mathrm{nr} 38,41)$.

Jasne są też zadania proboszcza w funkcjonowaniu poradni - w świetle omawianego dyrektorium to przede wszystkim: powoływanie, wspieranie rozwoju, wynagradzanie doradców, dbałość o materialne warunki pracy poradni (nr 42).

W każdej diecezji powinna istnieć Diecezjalna Specjalistyczna Poradnia Rodzinna (a w miarę możliwości Rejonowe bądź Dekanalne Specjalistyczne Poradnie Rodzinne). Poradnie takie w celu zapewnienia zgłaszającym się integralnej pomocy powinny zatrudniać różnych specjalistów. Oprócz duszpasterza mają w nich pracować między innymi: psycholog, pedagog, prawnik, lekarz (konsultant), nauczyciel naturalnego planowania rodziny. W poradni powinien znajdować się tak zwany bank informacji o możliwościach dalszej pomocy w skomplikowanych sytuacjach życiowych (między innymi o Domach Samotnych Matek, Ośrodkach Adopcyjno-Opiekuńczych, Ośrodkach Pomocy Społecznej) (nr 43). Dla pragnących skorzystać z pomocy w sposób anonimowy powinien działać, przynajmniej jeden w diecezji telefon zaufania (nr 44).

Dyrektorium jest pierwszym dokumentem, który w tak bezpośredni i szczegółowy sposób podejmuje zagadnienie organizowania poradni rodzinnych, działających w obrębie Kościoła katolickiego. Zawiera wiele konkretnych wskazań, wytycznych, które niestety wciąż w niewystarczającym stopniu są realizowane w rzeczywistości. Diecezjalne Specjalistyczne Poradnie Rodzinne posiadają zadowalające zaplecze: przygotowaną kadrę, odpowiednie pomieszczenia, wyposażenie, natomiast Parafialne Poradnie Rodzinne wciąż funkcjonują w ograniczonym zakresie, często w warunkach dalekich od opisywanych w dyrektorium (poradnictwo kierowane jest głównie do narzeczonych, spotkania odbywają się w niedostosowanych do tego pomieszczeniach, doradcy nie zawsze otrzymują wynagrodzenie $)^{20}$.

20 Por. A. Mrozowicz, dz. cyt. 


\section{Formy poradnictwa rodzinnego opartego na wartościach chrześcijańskich}

Wraz z rozwojem poradnictwa ewoluowały jego formy: od nauczania instrumentalnego (kształcenia umiejętności stosowania naturalnych metod planowania rodziny czy poznania doktryny Kościoła na temat małżeństwa i rodziny) do formowania przede wszystkim wnętrza człowieka, jego postaw. Przyjęto, że zasadniczą formą pracy w poradnictwie ma być formacja wewnętrzna człowieka - zaproszenie go do pełnego uczestnictwa w życiu Kościoła i wspólnot. Dzisiaj jest to zasadnicze podejście do poradnictwa. Przyświeca temu zasada, że tylko doradca ,praktykujący”, świadek żywej wiary ma moc oddziaływania ${ }^{21}$.

Rzeczywiście, doradcy rodzinni posługujący przy Kościele to osoby, które zazwyczaj dbają o tę wewnętrzną formację, biorąc udział w spotkaniach formacyjnych, rekolekcjach czy aktywnie uczestnicząc w życiu Kościoła. Niestety, nie zawsze można tak powiedzieć o osobach, które trafiają do doradców rodzinnych (najczęściej ze względu na obowiązek przygotowania się do sakramentu małżeństwa). Wciąż bardziej zabiega się o ich przygotowanie do stosowania metod naturalnej regulacji poczęć (głównie w zakresie poznania technik), pomijając lub ograniczając formację ich wnętrza, rozwój postawy miłości, wzajemnego zrozumienia. Jest to zasadniczy błąd. Najpierw trzeba pobudzić narzeczonych czy małżonków do refleksji nad posiadaną już przez nich wiedzą - jaka to wiedza, skąd pochodzi, jakie są efekty jej stosowania? Zanim przystapimy do nauki metod i technik tak zwanego NPR (naturalnego planowania rodziny), należy uzasadnić, dlaczego warto je znać i kiedy stosować2 ${ }^{22}$. Wszystkie te wiadomości zostaną łatwiej i pełniej przyswojone przez osoby o odpowiednio uformowanym sumieniu.

Poradnictwo rodzinne w Kościele świadczone jest na drodze kontaktów indywidualnych (z narzeczonymi, małżeństwami) i oddziaływań gru-

${ }^{21}$ M. Szarecka, Poradnictwo rodzinne w archidiecezji gdańskiej, referat wygłoszony na konferencji $W$ trosce o rodzine 17 listopada 2006 w Gdańsku, organizowanej przez Human Life International, opublikowany na stronie internetowej: http://www.hli.org.pl/pl/wd/konferencjaw-trosce-o-rodzine/ (03.11.2011).

${ }^{22}$ Uważać należy, aby NPR nie utożsamiano z „ekologiczną antykoncepcją”, doradca rodzinny zawsze ma podkreślać dwojakie znaczenie stosunku małżeńskiego: jedność i rodzicielstwo (HV 12). Papież Paweł VI wyraźnie podkreślił: „Jeśli więc istnieją słuszne powody dla wprowadzenia przerw między kolejnymi urodzeniami dzieci, wynikające bądź z warunków fizycznych czy psychicznych małżonków, bądź z okoliczności zewnętrznych" - jedynie wówczas Kościół dopuszcza stosowanie NPR (HV 16). 
powych - z dziećmi i młodzieżą, z grupami przygotowującymi się do małżeństwa, z rodzicami przed chrztem dziecka, z rodzicami i grupami zawodowymi (na przykład z nauczycielami, lekarzami). Poradnictwo przyjmuje wówczas postać nauczania, porady, ćwiczenia ${ }^{23}$. Są to formy jak najbardziej charakterystyczne i właściwe w poradnictwie. Należy jednak uzupełniać je dyskusją czy również wykorzystaniem multimediów. Warto też bardziej rozwinąć pracę z małymi grupami - z rodzicami, małżonkami, ukierunkowaną zarówno na wewnętrzną duchową formację, jak i nabywanie konkretnych społecznych umiejętności: wychowawczych, porozumiewania się, rozwiązywania konfliktów.

\section{Cele i zadania poradnictwa rodzinnego opartego na wartościach chrześcijańskich}

Poradnictwo rodzinne, oparte na wartościach chrześcijańskich, posiada własną specyfikę, jest wyjątkowe w porównaniu do poradnictwa świeckiego. Jedną z jego cech charakterystycznych są wyjątkowe cele.

Chrześcijański doradca, zmierzając do osiagnięcia typowych dla świeckiego poradnictwa celów, na przykład: pomocy w zrozumieniu siebie, nauki komunikowania się z innymi, uczenia się i zmiany zachowań, pomocy w samorealizacji, udzielenia wsparcia, dąży też do rozwoju duchowego człowieka. Stara się stymulować wzrost duchowy osoby otrzymującej poradę, zachęca ją do odkrywania mocy modlitwy, do wyznawania własnych grzechów i doświadczania przebaczenia Bożego, korzystania z sakramentów, promuje chrześcijański styl życia, pragnie przekazać wartość przesłania Ewangelii w życiu każdego człowieka.

Można oczywiście krytykować takie podejście do poradnictwa ze względu na „mieszanie” religii w sprawy specjalistycznej pomocy. Wiadomo, że żaden dobry doradca nie powinien narzucać swoich przekonań osobie otrzymującej poradę, ponieważ ma obowiązek traktować ją z szacunkiem i zapewnić wolność w podejmowaniu decyzji. Jednak dobry doradca to także ten, którego szczerość i autentyczność nie pozwoli na pozostawienie własnych przekonań „w domu” i udawanie kogoś, kim nie jest. Poza tym, nie można ignorować przekonań religijnych osoby szukającej pomocy. Jeżeli deklaruje ona swoją wiarę, należy na niej właśnie budować cały proces pomocy $^{24}$.

\footnotetext{
23 Tamże.

${ }^{24}$ Por. G. R. Collins, Poradnictwo chrześcijańskie, Warszawa 2005, s. 28-29.
} 
Cele poradnictwa rodzinnego opartego na wartościach chrześcijańskich można wyodrębnić na podstawie treści zawartych we wspomnianych już dokumentach: encyklice Humanae vitae i adhortacji Familiaris consortio.

W Humanae vitae znajduje się wezwanie do nawrócenia do świętości w każdym stanie. Można je uznać także za cel poradnictwa rodzinnego: pomagać ludziom żyć w sposób święty. Małżonkowie powołani do wielkiej współpracy z samym Stwórca, jako współpracownicy Boga w dziele stworzenia, mają szczególne zadanie i szczególną odpowiedzialność: im więcej dano, tym więcej będzie od nich wymagane. Ponieważ małżonkowie otrzymali od Boga płodność - dar przekazywania życia, mają wykorzystywać go zgodnie z Bożym zamiarem (HV 9) ${ }^{25}$.

Ważnym celem poradnictwa rodzinnego jest wychowanie do czystości. Jan Paweł II przypominał, że jest ono nieodzowne, że „,doprowadza osobę do prawdziwej dojrzałości i uzdalnia ją do szanowania i rozwijania «oblubieńczego sensu» ciała" (FC 37). Celem poradnictwa rodzinnego ma być uświadomienie ludziom potrzeby życia w czystości zarówno w stanie wolnym, jak i w małżeństwie. Owa czystość to zdolność panowania nad popędami ciała, tak aby służyły, a nie zagrażały rozwojowi osobowemu i umacnianiu miłości.

O tym, jakich małżonków ma formować poradnictwo rodzinne (małżeńskie), dowiadujemy się nie tylko z Humanae vitae, ale z samych kart Pisma Świętego, dlatego nie będziemy teraz wymieniać wszystkich pożądanych cech małżonków. Zaznaczmy tylko, że celem poradnictwa rodzinnego jest uświadamianie małżonkom istoty i wartości obiecywanej niegdyś sobie miłości, wierności, uczciwości małżeńskiej, a także wyposażenie ich w umiejętności rozwijania, wzmacniania tych cech.

Celem poradnictwa rodzinnego można określić także upowszechnianie wartości moralnych, które służą człowiekowi i rodzinie. Upowszechnianie to ma kształtować moralne sumienie, uzdalniające człowieka do osądzania i rozpoznawania właściwych sposobów urzeczywistniania siebie. Taki cel stawiają sobie doradcy, spotykając się z narzeczonymi, małżonkami czy innymi osobami przeżywającymi radości i trudności życia małżeńskiego czy rodzinnego ${ }^{26}$.

W poradnictwie rodzinnym, opartym na wartościach chrześcijańskich, człowiek nie może usłyszeć słów akceptacji dla: pożycia pozamałżeńskiego, przemocy czy braku przebaczenia w rodzinie - tu należy szukać sposobów

${ }^{25}$ Papież Paweł VI przypomniał: „Małżeństwo i miłość małżeńska z natury swej skierowane są ku płodzeniu i wychowywaniu potomstwa. Dzieci są też najcenniejszym darem małżeństwa i samym rodzicom przynoszą najwięcej dobra" (HV 9).

${ }^{26} \mathrm{http}: / / w w w . d k . s z c z e c i n . p l / a p o s t o l s t w o-w-r o d z i n i e /(03.11 .2011)$. 
uleczenia trudnych relacji, a nie ich niszczenia. Nie ma tu przyzwolenia na antykoncepcję, aborcję, in-vitro, eutanazję - czyli wszystkie zabiegi uderzające w godność osoby ludzkiej. Choć poradnictwo rodzinne usytuowane przy Kościele ma służyć wszystkim: „Przyjdźcie do mnie wszyscy, którzy utrudzeni i obciążeni jesteście... (Mt 11,28)", to nigdy nie może unikać nazywania rzeczy po imieniu: zła złem, dobra dobrem, zgodnie ze znaną w środowisku ,pomocowym” zasadą: oceniamy zachowania, a nie osoby.

Podstawowe wartości, jakie mają być upowszechniane w chrześcijańskim poradnictwie rodzinnym, to świętość życia ludzkiego, godność osoby ludzkiej, miłość i służba dla drugiego człowieka, wartość rodziny.

Zgodnie z przywoływanym już wyżej tekstem Dyrektorium Duszpasterstwa Rodzin, wydanym w 2003 roku, poradnictwo rodzinne realizowane przy parafiach ma spełniać określone zadania: ukazywanie właściwego wymiaru miłości małżeńskiej i rodzinnej, w tym czystości przedmałżeńskiej i małżeńskiej; uwrażliwianie na godność każdego człowieka od chwili poczęcia do naturalnej śmierci; kształtowanie postaw prorodzinnych; nauczanie zasad odpowiedzialnego rodzicielstwa; pomoc w rozwiązywaniu konfliktów rodzinnych i problemów wychowawczych (nr 39). Wymienione zadania służą realizacji opisanych wyżej celów poradnictwa rodzinnego.

\section{Zakończenie}

Poradnictwo rodzinne w Kościele katolickim w Polsce zyskuje coraz więcej możliwości rozwoju, co wynika z przedstawionej w tej pracy jego historii i z przeanalizowanych dokumentów. Początkowo, jako odpowiedź na wprowadzenie $\mathrm{w}$ życie ustawy o dopuszczalności przerywania ciąży w latach pięćdziesiątych XX wieku, koncentrowało się głównie na uczeniu planowania rodziny przez stosowanie metod naturalnych, obecnie stawia się przed nim inne zadania.

Choć brakuje rzetelnych, wszechstronnych badań naukowych nad stanem katolickiego poradnictwa rodzinnego, to i bez nich, opierając się jedynie na zapoznaniu się $\mathrm{z}$ ofertą parafialnych poradni rodzinnych czy na przywołanym już w tej pracy raporcie A. Mrozowicz (o sytuacji poradnictwa rodzinnego w Archidiecezji Gdańskiej z 2008 roku), można zauważyć, że pojawiające się możliwości rozwoju wykorzystywane są jedynie częściowo. Wciąż w katolickim poradnictwie rodzinnym dominuje nauczanie metod naturalnego planowania rodziny, kierowane głównie do narzeczonych. Nie jest ono łatwym zadaniem, o czym pisze jedna z osób odpowiedzialnych za realizowanie tego zadania: 
Dzisiaj poradnictwo rodzinne dysponuje przygotowaną kadrą, która służy życiu. Wobec ogromnych potrzeb nieustannie posuwa się naprzód, chociaż niejednokrotnie praca doradców to walka z wiatrakami. Wynika to z faktu, że ludzie żyją w świecie pełnym presji płynącej głównie ze środków masowego przekazu, nie zawsze potrafią uchronić się przed zaciemnianiem podstawowych wartości oraz stać się krytycznym sumieniem kultury rodzinnej ${ }^{27}$.

W katolickim poradnictwie rodzinnym zauważa się braki w zakresie oferty dla małżeństw, rodziców, młodzieży. Skąd te słabości? Spowodowane moga być brakiem funduszy na zatrudnienie wykwalifikowanych specjalistów i na stworzenie odpowiedniego zaplecza (pomieszczeń, wyposażenia) poradni. To jednak zbyt oczywiste i zarazem zbyt „wygodne” uzasadnienie. Wydaje się, że wielu duszpasterzy nie zdaje sobie sprawy, jakie są potrzeby i realne możliwości niesienia konkretnej pomocy rodzinom, lub uznaje, że wystarczy samo duszpasterstwo rodzin. Dlatego nie zabiegają o materialną stronę działania poradni, niekiedy nie wspierają doradców życia rodzinnego w nabywaniu dodatkowych kwalifikacji, nie zatrudniają takich specjalistów, jak psycholog, prawnik, licząc jedynie na usługi wolontarystyczne. Analizowany w tej pracy dokument Dyrektorium Duszpasterstwa Rodzin w znacznej mierze pozostaje tylko zapisem, część poświęcona organizowaniu poradnictwa rodzinnego przy parafiach nie jest w pełni urzeczywistniana.

Rodzinom, małżonkom przeżywającym trudności pozostaje więc szukanie pomocy w instytucjach świeckich lub korzystanie z prywatnej praktyki psychologa, terapeuty itp. Tam natomiast mogą oni nie znaleźć odniesienia do wartości chrześcijańskich, tak ważnych dla utrzymania trwałości i głębi więzi między małżonkami, czy też do rozwiązania problemów wychowawczych z dziećmi.

W obecnych czasach życie w rodzinie wiąże się z przeżywaniem wielu trudności. Jesteśmy wychowywani do bycia bardziej dla siebie niż dla innych, raczej do używania niż do dawania, do dbania przede wszystkim o siebie. Dlatego w zderzeniu z problemami czy konfliktami w życiu rodzinnym tak często dochodzi do rozpadu związku. Poradnictwo rodzinne realizowane w Kościele katolickim opiera się na zupełnie „nieświeckich” i mało atrakcyjnych w potocznym rozumieniu wartościach chrześcijańskich, takich jak: świętość, czystość w sferze seksualności, określone normy moralne, odpowiedzialne rodzicielstwo (w poszanowaniu daru przekazywania życia - płodności). Choć dzisiejsza kultura tak bardzo się od tego oddala, nie sposób zaprzeczyć, że to właśnie te wartości, nie inne, służą małżeństwu i rodzinie. W tym tkwi specyfika i wyjątkowość katolickiego poradnictwa

${ }^{27} \mathrm{http}: / /$ www.dk.szczecin.pl/apostolstwo-w-rodzinie/ (03.11.2011) 
rodzinnego, że odnosi się wprost do tych wartości, zabiegając przy tym o duchowy rozwój człowieka.

\section{The Need for the Development of Family Counselling Based on Christian Values - Illustrated by the Example of the Activities of the Catholic Church in Poland (Summary)}

Family counselling is one of the forms of assistance offered to families today. However, the secular foundations of family counselling are increasingly moving away from Christianity. The secular law normalizes the situations that in fact weaken the value of marriage and family because it helps create policies that offer lofty assumptions, but in reality appear to work against families rather than for them.

The article presents the history of family counselling, in both public institutions and the Catholic Church. It analyses the Church documents that justify the need for the development of family counselling, explain its foundations, specificity, and propose its structure.

The article leads to the following conclusion: the Catholic family counselling is based on completely "non-secular" and not very attractive - in the common sense - Christian values, such as holiness, sexual purity, defined moral standards and responsible parenthood (in respect of the gift of giving life - fertility).

Even though the modern culture tries to move away from these, it cannot be denied that it is particularly those values, not other, that serve for the benefit of marriage and family. That is the specificity and uniqueness of the Catholic family counselling - it relates directly to these values, and at the same time strives for the spiritual development of a man. 